\title{
ZASADA „ZANIECZYSZCZAJĄCY PŁACI” \\ W CZESKIM PRAWIE ŚRODOWISKA W PORÓWNANIU Z PRAWEM POLSKIM
}

\section{"POLLUTER PAYS" PRINCIPLE IN THE CZECH ENVIRONMENTAL LAW IN COMPARISON WITH THE POLISH LAW}

http://dx.doi.org/10.12775/PPOS.2015.009

Artykuł recenzyjny

Ondřej Vicha

Princip „znečišt'ovatel plati” z pravniho pohledu Linde - Praha - 2014, ss. 234

\section{STRESZCZENIE}

Celem tego szkicu jest przedstawienie rozważań czeskiego autora Ondřeja Vichy poświęconych analizie prawnej zasady „zanieczysz-

* Magister prawa, Zakład Zagadnień Prawnych Kształtowania i Ochrony Środowiska, Instytut Nauk Prawnych PAN.

** Prof. dr hab., Kierownik Zakładu Zagadnień Prawnych Kształtowania i Ochrony Środowiska, Instytut Nauk Prawnych PAN. 
czający płaci" w świetle prawa międzynarodowego, unijnego i czeskiego. Podstawową wagę przywiązujemy do rozważań odnoszących się do instrumentów realizacyjnych zasady „zanieczyszczający płaci” $\mathrm{w}$ czeskim prawie ochrony środowiska. Rozwiązania czeskie konfrontujemy z ich odpowiednikami w prawie polskim.

\section{Słowa kluczowe}

Zanieczyszczenie środowiska; podatki; opłaty; odpowiedzialność prawna.

\section{ABSTRACT}

The aim of this paper is to present the deliberations of the Czech author Ondřej Vicha devoted to the analysis of ,polluter pays principle' under the international, EU and Czech law. The major significance is attached to the deliberations on the instruments implementing ,polluter pays principle' in the Czech environmental law. These instruments are compared with their equivalents in the Polish law.

\section{Keywords}

Environmental pollution; taxes; fees; legal liability.

\section{WSTĘP}

W praskim wydawnictwie „Linde” ukazała się w 2014 roku monografia Ondřeja Vichy, pracownika naukowego Katedry Prawa Administracyjnego i Nauk Administracyjnych Wydziału Prawa Uniwersytetu Palackiego w Ołomuńcu, poświęcona analizie znanej w ochronie środowiska zasady „zanieczyszczający płaci” od strony prawnej. Rozważania autora są tak interesujące, że zdecydowaliśmy się je zaprezentować czytelnikowi polskiemu. Wprawdzie polska doktryna prawa środowiska wielokrotnie zajmowała się tą zasadą, ale nie powstała u nas monografia wyłącznie jej poświęcona, dlatego chcielibyśmy spojrzeć na monografię czeską także z perspektywy polskiej. Jedynie w skrócie zasygnalizujemy to, co Ondřej Vicha ma do powiedzenia w kwe- 
stii analizowanej zasady w aspekcie prawa międzynarodowego, unijnego i amerykańskiego, skoncentrujemy się na koncepcji teoretycznej i prawie czeskim oraz spróbujemy porównać rozwiązania czeskie tak jak je przedstawia autor monografii z rozwiązaniami polskimi.

Ondřej Vicha ujął swe rozważania w siedmiu rozdziałach:

1. Zasady prawne, ich pozycja i funkcje w systemie prawa w ogólności, a zwłaszcza w prawie środowiska.

2. Rozwój i funkcje zasady „zanieczyszczający płaci”, jej stosunek do pozostałych zasad prawa środowiska oraz instrumenty ją wprowadzające.

3. Zasada „zanieczyszczający płaci” w prawie międzynarodowym.

4. Zasada „zanieczyszczający płaci” w prawie unijnym.

5. Zasada „zanieczyszczający płaci” w czeskim porządku prawnym.

6. Zasada „zanieczyszczający płaci” w regulacji prawnej USA.

7. Wyznaczenie granic zasady „zanieczyszczający płaci” oraz niedociągnięcia w jej stosowaniu.

Monografię kończą krótkie podsumowanie, streszczenie angielskie oraz imponujący wykaz wykorzystanej literatury światowej i czeskiej.

\section{TEORETYCZNE UJĘCIE ZASADY „ZANIECZYSZCZAJĄCY PŁACI”}

Przedmiotem rozdziałów 1 i 2 jest teoretyczne podejście do zasady „zanieczyszczający płaci”. Punktem wyjścia rozważań jest koncepcja zasad prawa jako obok norm prawnych najbardziej znaczących części obiektywnego porządku prawnego. Zasady różnią się od norm większym stopniem ogólności, możliwym kontradyktoryjnym charakterem oraz specyficznym znaczeniem i sposobem posługiwania się nimi w systemie prawnym. Z zasad prawa nie wypływają bezpośrednio uprawnienia ani obowiązki. 
Prawo środowiska (pravo životniho prostředi) uznaje autor za relatywnie samodzielną gałąź prawa. Zauważa, że ochrona środowiska jest od swego początku przeniknięta dążeniem do sformułowania pewnych ogólnych postulatów, które wyrażałyby, w nawiązaniu do specyfiki środowiska, potrzebę ochrony, cel i wytyczane zamiary. W różnych źródłach prawa międzynarodowego, unijnego i wewnętrznego zaczęły się objawiać liczne zasady ochrony środowiska (niekiedy oznaczane mianem „environmentalnych zasad"), niektóre z nich stopniowo zyskały powszechne uznanie.

Odwołując się do podstawowego czeskiego podręcznika prawa środowiska ${ }^{1}$ wskazuje na następujące zasady: najwyższej wartości, wysokiego stopnia ochrony, trwale zrównoważonego rozwoju, odpowiedzialności państwa, kompleksowej i zintegrowanej ochrony, prewencji, przezorności, informowania i uczestnictwa społeczeństwa oraz zasady stymulacji ekonomicznej i odpowiedzialności sprawcy, które są ściśle związane z zasadą „zanieczyszczający płaci”. Zauważa, że pojawia się nowy rodzaj zasad, które nie mają jedynie na celu racjonalizowania prawa bądź wypełniania luk, ale mają prowadzić do tworzenia publicznych polityk. Do takich programowych zasad zalicza właśnie zasadę „zanieczyszczający płaci”, zgodnie z którą - w najogólniejszym ujęciu - kto powoduje zanieczyszczenie środowiska, jest zobowiązany za to płacić i ponosić koszty zapobiegania, kontroli i usuwania zanieczyszczeń. Ondřej Vicha trafnie wskazuje, że prostota tej zasady jest złudna, pojawia się bowiem szereg pytań (kto jest zanieczyszczającym, czy jest nim np. prowadzący samochód, za co ma płacić, komu, kiedy i w jakiej wysokości, czy inwestycje w urządzenia ochronne lub czyste technologie są taką płatnością, i wiele innych), na które dopiero trzeba znaleźć odpowiedzi.

Zasada „zanieczyszczający płaci” została po raz pierwszy zdefiniowana i wprowadzona jako międzynarodowo uznana zasada na początku lat 70. ubiegłego wieku w zaleceniach OECD z 1972 r. Rada OECD traktowała ją jako zasadę ekonomiczną,

1 M. Damohorsky a kolektiv, Pravo životniho prostředi, Praha 2010, s. 5054. 
pozwalającą najskuteczniej pozyskać środki na zapobieganie zanieczyszczeniom i prowadzenie kontroli przez instytucje publiczne; została ona rozwinięta w rekomendacjach OECD z lat 1974 i 1989. Zasada ta za sprawą działalności ONZ znalazła się w niewiążących dokumentach międzynarodowych: Deklaracji Sztokholmskiej z 1972 r. i Deklaracji z Rio de Janeiro z 1992 r. Z biegiem czasu badana zasada znalazła się w licznych umowach międzynarodowych, przeniknęła do aktów prawnych Unii Europejskiej oraz do wewnętrznych systemów prawnych wielu państw.

Interesujące są uwagi autora o funkcjach zasady „zanieczyszczający płaci". Wyodrębnia trzy podstawowe funkcje: integracji ekonomicznej (dominowała we wczesnych rekomendacjach OECD, kiedy miała zapobiegać skrzywieniom $\mathrm{w}$ międzynarodowym handlu i inwestycjach), redystrybucyjną (z tego punktu widzenia zasada jest krytykowana jako pozwalająca „kupić prawo do zanieczyszczania”, ale z drugiej strony umożliwia organom administracji pozyskać środki na ochronę środowiska) i prewencyjną (znajdującą wyraz ex ante w opłatach za zanieczyszczenia a ex post w odpowiedzialności za straty w środowisku). Autor zauważa, że instytucja odpowiedzialności za straty w środowisku pozwala zasadzie „zanieczyszczający płaci" przypisać także funkcję kompensacyjną.

Wnikliwe analizy poświęcił autor relacjom między zasadą „zanieczyszczający płaci” a innymi zasadami prawa środowiska. Wychodzi z założenia, że zasada „zanieczyszczający płaci” jest wynikiem wzajemnego oddziaływania dwóch zasad prawa środowiska: zasady odpowiedzialności sprawcy (princip odpovědnosti puvodce) z jednej strony i zasady ekonomicznej stymulacji (princip ekonomicke stimulace) z drugiej. Poza tym ma ona ścisłe związki z zasadą prewencji (princip prevence) i zasadą przezorności (princip předběžne opatrnosti). Prymarnie zasada „zanieczyszczający płaci” jest konkretyzacją zasady stymulacji ekonomicznej, w której chodzi o to, aby zachowanie ekologiczne było korzystne ekonomicznie, i odwrotnie. Podstawą zasady stymulacji ekonomicznej jest wprowadzenie za zachowania jeszcze prawem dozwolone takich płatności, które zanieczyszczający będzie uznawał za tak wysokie, że „opłaci” mu się wy- 
łożyć środki na urządzenia bardziej uwzględniające wymagania środowiska i ich eksploatację. Obok tego zasada „zanieczyszczający płaci" jest rozwinięciem powszechnej zasady odpowiedzialności sprawcy, która oznacza, że każdy odpowiada za swoje działania zagrażające środowisku lub pogarszające jego stan. Odpowiedzialność polega na zrekompensowaniu wyrządzonej szkody lub usunięciu ekologicznej ujmy², które nie są koniecznie związane z naruszeniem prawa.

Zasada prewencji wyraźnie zmienia podejście oparte na zasadzie „zanieczyszczający płaci”, ponieważ wychodzi z potrzeby nie tyle naprawiania już wyrządzonych szkód, ile zapobiegania im. Podczas gdy zasady prewencji i „zanieczyszczający płaci” w jakimś sensie legitymizują pewien stopień uszkodze-

2 Czytelnikowi polskiemu należy się nieco szersze wyjaśnienie relacji między szkodą z ujmą. Otóż obowiązujący od 1 stycznia 2014 r. nowy kodeks cywilny Republiki Czeskiej (zakon č. 89/2012 Sb., občansky zakonik) zasadniczo zmienił dotychczasową konwencję językową i w części czwartej o względnych prawach majątkowych w rozdziale III „Zobowiązania z deliktów” (Zavazky z deliktu) w oddziale 1 „Naprawienie ujmy majątkowej i niemajątkowej" (Nahrada majetkove a nemajetkove ujmy) zrezygnował z operowania pojęciem „odpowiedzialności”. Podstawowy § 2894 w ust. 1 stanowi w czeskim oryginale, że: „Povinnost nahradit jinemu ujmu zahrnuje vždy povinnost k naradě ujmy na jmeni (škody)". Przepis ust. 2 tegoż § 2894 przytoczymy już w tłumaczeniu: „Jeżeli obowiązek wynagrodzenia innemu niemajątkowej ujmy nie został wprost uzgodniony, dotyka sprawcy szkody tylko jeżeli tak stanowi ustawa szczególna. W takich przypadkach obowiązek wynagrodzenia niemajątkowej ujmy przez danie zadośćuczynienia ocenia się podobnie według przepisów o obowiązku naprawienia szkody". Z tego wynika, że kodeks jako pojęcie nadrzędne przyjął ujmę. Czeska ujma jest w słownikach oddawana jako polskie: „uszczerbek, szkoda, strata, ujma”. W ramach ujmy ustawodawca czeski rozróżnia: ujmę na mieniu (ujma na jmeni) będąca szkodą (škoda), która wynagradza się zawsze, i ujmę niemajątkową (nemajetkova ujma), wynagradzaną tylko wtedy, gdy strony stosunku zobowiązaniowego tak się umówiły, a w pozostałych przypadkach, tylko jeżeli ustawa szczególna tak stanowi, wtedy zaś postępuje się tak samo jak przy wynagradzaniu szkody majątkowej. Oficjalne uzasadnienie projektu kodeksu cywilnego głosi, że wprawdzie większość przepisów oddziału 1 utrzymuje pojęcie szkody, ale stosuje się je także do niemajątkowej ujmy, jeżeli z porządku prawnego wynika obowiązek wynagrodzenia jej (zob. K. Eliaš a kolektiv, Novy občansky zakonik s aktualizovanou diovodovou zpravou a rejstřikem, Ostrava 2012, s. 1022). Zrozumiałe jest, że ustawodawca czeski nie używa pojęcia „szkoda ekologiczna”, lecz zawsze „ujma ekologiczna”. 
nia środowiska, „najmłodsza” zasada przezorności wyznacza inną granicę. W duchu tej zasady organy administracji publicznej muszą być przygotowane i na możliwe, niepewne czy hipotetyczne niebezpieczeństwo, tedy na przypadki, gdy nie istnieje żaden jednoznaczny dowód, że niebezpieczeństwo nie pojawi się.

Szczególnie interesujące są rozważania Ondřeja Vichy nad instrumentami wdrażającymi zasadę „zanieczyszczający płaci”. Wyróżnia instrumenty ekonomiczne, które są uzupełniane instrumentami odpowiedzialności w postaci odpowiedzialności za straty w środowisku, ewentualnie także instrumentami sankcyjnymi w postaci kar pieniężnych (pokut). Podczas gdy instrumenty ekonomiczne wdrażają zasadę „zanieczyszczający płaci” ex ante i pełnią tym samym funkcję motywacyjną (prewencyjną), instrumenty odpowiedzialności przedstawiają wobec niej podejście ex post i pełnią zwłaszcza funkcję kompensacyjną.

Do instrumentów ekonomicznych wdrażających zasadę „zanieczyszczający płaci” autor zalicza różnego rodzaju opłaty, należności czy płatności za zanieczyszczenia czy inne uszkodzenia (obciążenia) środowiska, podatki ekologiczne oraz systemy handlu pozwoleniami na emisję, a także reguły udzielania pomocy publicznej na ochronę środowiska. Opłaty różnią się od podatków zwłaszcza akcentem na ich motywacyjne (stymulacyjne) funkcje i celowym powiązaniem z ochroną środowiska, których to cech podatki nie wykazują. Najistotniejsze z punktu widzenia zasady „zanieczyszczający płaci” są opłaty za zanieczyszczenia środowiska (emisni poplatky) najczęściej stosowane w ochronie powietrza i wód, a także w regulacji dotyczącej umieszczania odpadów na składowiskach.

W kwestii odpowiedzialności autor przychylając się do poglądów literatury operuje pojęciem odpowiedzialności ekologiczno-prawnej, która składa się z dwóch podstawowych części: odpowiedzialności za straty w środowisku (odpovědnost za ztraty na životnim prostředi) i odpowiedzialności deliktowej (deliktni odpovědnost), która występuje w dwóch formach: odpowiedzialności karnej (trestni odpovědnost) za przestępstwa i odpowiedzialności administracyjnej (spravni odpovědnost) za wykroczenia i inne delikty administracyjne. Autor zastrzega, że 
z punktu widzenia zasady „zanieczyszczający płaci” zajmuje się tylko odpowiedzialnością za straty w środowisku, ale dostrzega, że niekiedy do instrumentów wdrażających tę zasadę zalicza się także kary pieniężne (pokuty), zauważając trafnie, że one - w odróżnieniu od podatków, opłat czy należności - nie są instrumentem ekonomicznym, lecz sankcyjnym za działania bezprawne $\mathrm{w}$ dziedzinie ochrony środowiska, np. za niedotrzymywanie limitów emisyjnych. Jakimś uzasadnieniem zaliczenia ich do instrumentów realizacyjnych zasady „zanieczyszczający płaci” jest to, że groźba ich ponoszenia stwarza ekonomiczną presję (ekonomicky natlak) ex ante, a faktyczne ich ponoszenie jest ekonomiczną represją (ekonomicky postih) ex post, a ponadto, że przychody z kar pieniężnych, tak jak i przychody z opłat i należności (ale już nie podatków) są celowo powiązane z nakładami na ochronę środowiska.

\section{ZASADA „ZANIECZYSZCZAJĄCY PŁACI” \\ W PRAWIE MIĘDZYNARODOWYM, UNIJNYM I AMERYKAŃSKIM}

Te zagadnienia są przedmiotem rozdziałów 3, 4 i 6 monografii. Nie będziemy ich omawiać, docenimy jedynie to, że Ondřej Vicha wykonał zaiste benedyktyńską pracę analizując niezwykle szczegółowo i kompetentnie kilkadziesiąt konwencji $\mathrm{w}$ rozdziale 3 oraz prawodawstwo unijne wraz $\mathrm{z}$ orzecznictwem TSUE w rozdziale 4. Zatrzymamy się jedynie krótko nad zgrabnymi rekapitulacjami tych rozdziałów. I tak podsumowując analizy „międzynarodowe” autor zauważa, że nie ma w nim opłat, a zasada „zanieczyszczający płaci” znajduje odzwierciedlenie w licznych konwencjach o odpowiedzialności za szkody w środowisku opartych na koncepcji odpowiedzialności obiektywnej, niezależnej od zawinienia. Specyficznymi sposobami realizacji tej zasady jest rozdzielenie obowiązku płacenia odszkodowań między np. właścicielami statków przewożących ropę lub materiały niebezpieczne a użytkownikami tych materiałów, a także utworzenie specjalnych funduszy odszko- 
dowawczych. Podsumowując analizy „unijne” autor wykazuje, że zasada „zanieczyszczający płaci” została wyrażona zarówno w prawie pierwotnym, jak i prawie wtórnym. Za pośrednictwem instrumentów ekonomicznych ta zasada jest w prawie unijnym wdrażana $\mathrm{w}$ ramach opodatkowania produktów energetycznych i elektryczności, opłat za korzystanie z dróg przez ciężkie samochody ciężarowe, opłat w ochronie wód, instrumentów ekonomicznych w legislacji dotyczącej odpadów oraz w systemie handlu pozwoleniami na emisję gazów cieplarnianych. Zasada „zanieczyszczający płaci” została wprowadzona do regulacji prawnej odpowiedzialności za szkody w środowisku, w ramy koncepcji rozszerzonej odpowiedzialności wytwórcy w legislacji dotyczącej odpadów oraz w związku z regułami udzielania pomocy publicznej na ochronę środowiska.

Krótki, liczący pięć stron rozdział 6 poświęcony prawu amerykańskiemu jest uzasadnionym koncepcją pracy ekskursem komparatystycznym.

W Polsce nikt nie badał szczegółowo zasady „zanieczyszczający płaci" w prawie międzynarodowym i unijnym. Warto jednak zwrócić uwagę na Piotra Korzeniowskiego, który wskazał instrumenty realizacji tej zasady, również w systemie prawnym Unii Europejskiej. W kręgu jego zainteresowań znalazło się prawo niemieckie, które posługuje się na oznaczenie tej zasady terminem „zasada odpowiedzialności sprawcy” oraz prawo obowiązujące w Holandii, gdzie wprowadzono system podatkowy, dzięki któremu znacznie ograniczono ilość odpadów metali ciężkich $^{3}$. Także Maria Magdalena Kenig-Witkowska wzmiankowała o tej zasadzie na gruncie prawa międzynarodowego ${ }^{4}$. Jej zdaniem jest ona interpretowana w dwojaki sposób:

1) „zasada PPP związana jest jedynie z kosztami działań prewencyjnych i walki z zanieczyszczeniami. Koszty te dotyczą działań przedsięwziętych przez zanieczyszcza-

3 Zob. P. Korzeniowski, Zasady prawne ochrony środowiska, Łódź 2010, s. $428-433$.

4 Zob. M. M. Kenig-Witkowska, Międzynarodowe prawo środowiska. Wybrane zagadnienia systemowe, Warszawa 2011, s. 70-72. 
jącego lub na jego rzecz, przez świadczących usługi, np. takie jak oczyszczanie, eliminacja odpadów itp.;

2) zasada PPP dotyczy wszystkich kosztów zanieczyszczenia wynikających bezpośrednio lub pośrednio z zanieczyszczenia spowodowanego przez danego zanieczyszczającego".

\section{ZASADA „ZANIECZYSZCZAJĄCY PŁACI” W PRAWIE CZESKIM}

Analizie prawa czeskiego poświęca Ondřej Vicha rozdział 5 swej monografii. Zaczyna od spostrzeżenia, że zasada „zanieczyszczający płaci" za pośrednictwem prawa międzynarodowego i unijnego przenika do porządku prawnego Republiki Czeskiej. Jest uregulowana na płaszczyźnie ogólnej w ustawie o środowisku ${ }^{5}$. Wprawdzie sama ustawa o zasadzie „zanieczyszczający płaci" nie wspomina wprost, ale można ją wyprowadzić zwłaszcza z regulacji odpowiedzialności za ujmę ekologiczną (§ 27) i instrumentów ekonomicznych (§ 31). Od siebie dodamy, że czeska ustawa o środowisku jest bardzo krótkim aktem prawnym, liczącym w wersji pierwotnej 35 paragrafów (obecnie 28, gdyż § 20-26 zostały uchylone), mieszczącym się na trzech stronach, będącym w istocie zbiorem definicji i zasad.

Autor monografii wskazuje, że zasada „zanieczyszczający płaci" jest wprowadzana zwłaszcza regulacjami prawnymi o odpowiedzialności za ujmę ekologiczną, zawartymi w samej ustawie o środowisku oraz w specjalnej ustawie o zapobieganiu ujmie ekologicznej i jej naprawianiu ${ }^{6}$. W ramach przepisów

5 Zakon č. 17/1992 Sb., o životnim prostředi. Przypominamy, jak powołuje się czeskie akty prawne: po literze „,̌.” (skrót od čislo, tj. „numer”) następuje pozycja, pod którą akt został opublikowany w oficjalnym zbiorze aktów prawnych - Sbirka zakonü, łamana przez rok publikacji i zakończona literami „Sb.” (skrótowcem owego zbioru).

6 Zakon č. 167/2008 Sb., o předchazeni ekologicke ujmě a o jeji napravě. Ustawa ta wdraża do czeskiego systemu prawnego dyrektywę 2004/35/WE Parlamentu Europejskiego i Rady z 21 kwietnia 2004 r. w sprawie odpowie- 
o odpowiedzialności zasady „zanieczyszczający płaci” dotyczą także regulacje odpowiedzialności za szkody na mieniu i zdrowiu człowieka zawarte $\mathrm{w}$ kodeksie cywilnym ${ }^{7}$, za szkody górnicze według prawa górniczego ${ }^{8}$ i za szkody jądrowe według prawa atomowego9. Przechodząc do ustaw odnoszących się do poszczególnych komponentów środowiska (složkove zakony) i zaliczając do nich m.in. ustawę o ochronie powietrza ${ }^{10}$, ustawę o odpadach ${ }^{11}$, ustawę wodną ${ }^{12}$, ustawę o ochronie rolniczych zasobów glebowych ${ }^{13}$ wskazuje, że wdrażają one zasadę „zanieczyszczający płaci" za pośrednictwem instrumentów ekonomicznych w postaci opłat za zanieczyszczenie środowiska (za ścieki, za zanieczyszczenie powietrza, za składowanie odpadów) oraz regulacji prawnej środków naprawczych (napravna opatřeni) zmierzających do usunięcia niepożądanego stanu. Obok nich umieszcza podatki ekologiczne wykazując, że zasadę „zanieczyszczający płaci” wdraża opodatkowanie olejów mineralnych, gazu ziemnego, paliw stałych i elektryczności. Jego zdaniem zasadę tę wdraża także całkiem nowy instrument ekonomiczny w postaci systemu handlu pozwoleniami na emisję gazów cieplarnianych. W końcowym fragmencie wywodu autor sygnalizuje, że teoretycznie można oceniać, iż zasada „zanieczyszczający płaci" przenika do regulacji prawnej odpowiedzialności deliktowej, tj. odpowiedzialności za wykroczenia, inne delikty administracyjne i przestępstwa. Chodzi o sankcje finansowe, które w odniesieniu do wykroczeń i innych deliktów administracyjnych noszą nazwę pokut, w odniesieniu zaś do przestępstw - penéžity trest. W obu wariantach są to kary

dzialności za środowisko w odniesieniu do zapobiegania i zaradzania szkodom wyrządzonym środowisku naturalnemu.

7 Zakon č. 89/2012 Sb., občansky zakonik.

8 Zakon č. 44/1988 Sb., o ochraně a využiti nerostneho bohactvi (horni zakon).

9 Zakon č. 18/1997 Sb., o mirovem využivani jaderne energie a ionizujiciho zařeni (atomovy zakon).

10 Zakon č. 201/2012 Sb., o ochraně ovzduši.

11 Zakon č. 185/2001 Sb., o odpadech.

12 Zakon č. 254/2001 Sb., o vodach (vodni zakon).

13 Zakon č. 334/1992 Sb., o ochraně zemědělskeho půdniho fondu. 
pieniężne, ale inaczej nazywane. Z tym fragmentem wywodu chcielibyśmy polemizować, bo naszym zdaniem właśnie teoretycznie - nie, skoro mamy do czynienia z sankcjami prawnymi, a nie środkami ekonomicznymi, co nieco wcześniej Ondřej Vicha sam przyznał. Na polemikę zasługuje także pogląd autora, że za przestępstwa przeciwko środowisku ${ }^{14}$ osobie fizycznej nie można wymierzyć kary pieniężnej, można taką karę wymierzyć tylko osobie prawnej na podstawie odrębnej ustawy ${ }^{15}$. Owszem, dostrzegamy, że przepisy § 293-308 czeskiego kodeksu karnego nie przewidują w sankcjach kary pieniężnej, ale - jeżeli dobrze odczytujemy regulacje kodeksowe i poglądy teoretyczne - można ją orzec na podstawie reguł wymierzania kar zamieszczonych w części ogólnej kodeksu ${ }^{16}$. Nie oznacza to, aby pokuty za wykroczenia czy peněžite tresty za przestępstwa były wyrazem zasady „zanieczyszczający płaci”, chodzi bowiem, naszym zdaniem, o odmienne instrumenty prawne - sankcje o charakterze penalnym.

Pełna prezentacja rozwiązań czeskich jest w ramach artykułu recenzyjnego niemożliwa. Zatrzymamy się przeto nad kilkoma problemami, które, naszym zdaniem, mogą być szczególnie interesujące dla czytelnika polskiego. Zaczniemy od odpowiedzialności za szkody i ujmę ekologiczną.

Za punkt wyjścia Ondřej Vicha przyjmuje § 415 „starego” kodeksu cywilnego ${ }^{17}$, który po zmianach wprowadzonych rychło po „aksamitnej rewolucji” listopada 1989 r. stanowił, że każdy powinien postępować tak, aby nie dochodziło do szkody na zdrowiu, mieniu, przyrodzie i środowisku. Nowy kodeks cywilny pominął ten powszechny obowiązek prewencyjny w zakresie środowiska, co w literaturze czeskiej jest oceniane jako osłabie-

14 Zakon č. 40/2009 Sb., trestni zakonik. Zvlaštni čast. Hlava VIII. Trestne činy proti životnimu prostředi (§ 293-308).

15 Zakon č. 418/2011 Sb., o trestni odpovědnosti pravnickych osob a řizeni proti nim.

16 J. Jelinek a kolektiv, Trestni pravo hmotne. Obecni čast. Zvlaštni čast, Praha 2013, s. 416.

17 Zakon č. 40/1964 Sb., občansky zakonik. 
nie cywilnoprawnej ochrony środowiska ${ }^{18}$. Po przeanalizowaniu rozwiązań nowego kodeksu cywilnego autor monografii ocenia, że ze względu na konieczność dokładnej kwantyfikacji szkody, odnoszenie jej tylko do komponentów środowiska będących przedmiotem własności, zasadę wolnej dyspozycji poszkodowanego środkami pozyskanymi tytułem odszkodowania, trudności w wykazaniu związku przyczynowego między zdarzeniem a szkodą, krótkimi terminami dochodzenia roszczeń ${ }^{19}$ instytucja naprawienia szkody w klasycznym ujęciu jest dla ochrony środowiska w szerszym zakresie w zasadzie nie do zastosowania.

Większe znaczenie przywiązuje autor do instytucji odpowiedzialności za ujmę ekologiczną. Została ona uregulowana dwutorowo, najpierw w ustawie o środowisku, która w $§ 10$ definiuje ujmę ekologiczną jako stratę lub osłabienie naturalnych funkcji ekosystemów, powstające wskutek uszkodzenia ich komponentów lub naruszenia wewnętrznych więzów i procesów w następstwie działalności człowieka. Autor podkreśla, że ujma ekologiczna jest rozumiana przede wszystkim jako niematerialna ogólnospołeczna strata w środowisku, którą odczuwa nie jeden podmiot (np. właściciel), lecz całe społeczeństwo. Ujma ekologiczna może być następstwem działań zarówno zgodnych z prawem, jak i bezprawnych. W odróżnieniu od szkody ujma ekologiczna powstaje i w tych komponentach środowiska, które nie są czy nie mogą być rzeczami (powietrze) i nie są przedmiotem własności (wody powierzchniowe i podziemne, dziko żyjące zwierzęta, jaskinie). Strata powstała w wyniku ujmy ekologicznej jest stratą nie tylko ze względów materialnych i ekonomicznych, ale i biologicznych, estetycznych, społecznych i kulturalnych (np. ingerencja w krajobraz). W odróżnieniu od

18 I. Jančařova, L. Bahyl'ova, M. Pekarek, I. Průchova, V. Vomačka, Odpovědnost v pravu životniho prostředi - současny stav a perspektivy, Brno 2013, s. 42 .

19 Jest to w jakimś sensie „tradycyjny” katalog przyczyn uzasadniających niewydolność „zwykłej” odpowiedzialności cywilnej w ochronie środowiska, sformułowany po raz pierwszy chyba przez M. Damohorskiego, Pravni odpovědnost za ztraty na životnim prostředi, Praha 1999, s. 165-166, wielokrotnie powtarzany $\mathrm{w}$ innych opracowaniach dotyczących odpowiedzialności w ochronie środowiska. 
klasycznej szkody przy ujmie ekologicznej nie wchodzi w rachubę finansowa rekompensata, możliwe jest jedynie wyliczenie kosztów przywrócenia stanu poprzedniego bądź kosztów przedsięwzięć kompensacyjnych.

Według § 27 ustawy o środowisku naprawienie ujmy ekologicznej jest możliwe na trzy sposoby. W pierwszym rzędzie jest to odnowienie naturalnych funkcji naruszonego ekosystemu lub jego części (restytucja naturalna, przywrócenie stanu pierwotnego). Jeżeli jest to niemożliwe lub niecelowe, sprawca ma obowiązek zrealizowania środków kompensacyjnych w inny sposób. Dopiero w trzeciej kolejności wchodzi w rachubę rekompensata pieniężna. Działania zasady „zanieczyszczający płaci” dopatruje się autor monografii w tym, że jeżeli sprawca nie wykonuje sam środków naprawczych, to płaci za ich wykonanie.

To jest jednak tylko teoria. W praktyce $\S 27$ ustawy o środowisku nie jest stosowany, ponieważ do dziś nie została wykonana zamieszczona w $\S 27$ ust. 1 delegacja do wydania przepisów, które regulowałyby sposób wyliczania ujmy ekologicznej i dalsze szczegóły. Efekt jest taki, że ujma ekologiczna jest naprawiana na podstawie innych ustaw. Jako przykład autor przytacza przewidziane w ustawie o ochronie przyrody i krajobrazu ${ }^{20}$ nasadzenia zastępcze po legalnym usunięciu drzew i krzewów.

Następnie autor przechodzi do specjalnej ustawy o zapobieganiu ujmie ekologicznej i jej naprawianiu. Ustawa ta doczekała się komentarza, którego Ondřej Vicha jest współautorem $^{21}$. Ustawa jest zbudowana na zasadzie „odpowiedzialności sprawcy" oznaczającej, że podmiot odpowiada za swoje działania, którymi zagraża lub uszkadza środowisko (wybrane części przyrody, woda i ziemia). Działania zasady „zanieczyszczający płaci" dopatruje się autor w obciążeniu sprawcy kosztami środków zapobiegawczych i naprawczych.

Wielce inspirujące są rozważania autora o środkach naprawczych, zdefiniowanych przez niego jako specyficzny instru-

20 Zakon č. 114/1992 Sb. o ochraně přirody a krajiny.

21 V. Stejskal, O. Vicha, Zakon o predchazeni ekologicke ujmě a o jeji napravě s komentařem, souvisejicimi predpisy a s uvodem do problematiky ekologicko-pravni odpovědnosti, Praha 2009. 
ment prawny naprawienia ekologicznie wadliwego (zavadneho) stanu, uregulowany w poszczególnych aktach prawnych z dziedziny ochrony środowiska. Istotą tego instrumentu jest zobowiązanie do czynienia czegoś, tj. do usunięcia wadliwego stanu. Związku z zasadą „zanieczyszczający płaci” dopatruje się autor w tym, że sprawca zanieczyszczenia powinien ponosić koszty tego działania. Te środki naprawcze dzieli na takie, który wynikają wprost z ustawy, oraz na takie, których przeprowadzenie jest nakazane decyzją administracyjną. Zauważa, że tylko ustawa o zapobieganiu ujmie ekologicznej i jej naprawie stanowi wprost, że koszty działań naprawczych ponosi sprawca. Ustawa wodna oraz niektóre inne nie zawierają wyraźnej regulacji dotyczącej kosztów. Ale, zdaniem autora, ciążący na sprawcy obowiązek poniesienia kosztów działań naprawczych należy wywodzić z zasady „zanieczyszczający płaci”.

Charakteryzując system podatkowy Republiki Czeskiej autor wyróżnia podatki bezpośrednie (dochodowe, majątkowe, z przeniesienia majątku) oraz podatki pośrednie (VAT i podatki akcyzowe). Za najistotniejsze z punktu widzenia zasady „zanieczyszczający płaci" uznaje autor podatki akcyzowe (spotrebni daně) przypominając, że także TSUE uznał je za wdrażające zasadę „zanieczyszczający płaci”. Wskazuje, że wprawdzie pojęcie „podatków ekologicznych” w obowiązującej czeskiej regulacji prawnej nie występuje, ale tak oznaczana jest „trójka” podatków: od gazu ziemnego i innych gazów, od paliw stałych i od energii elektrycznej.

Przechodząc do problematyki opłat Ondřej Vicha zaczyna od opłat za zanieczyszczenie powietrza. Przypomina, że mają one długą tradycję, zostały wprowadzone jeszcze w okresie czechosłowackim $^{22}$. W obowiązującym stanie prawnym są regulowane ustawą z 2012 r. o ochronie powietrza. Obowiązek ich ponoszenia ciąży na użytkownikach stacjonarnych źródeł zanieczyszczeń, ale nie wszystkich, ponieważ od opłat zwolnieni są użytkownicy mniejszych źródeł takich jak kotłownie w budynkach publicznych, lakiernie, piekarnie, urządzenia grzewcze w gospodarstwach domowych. Rozwiązanie to autor uważa za

22 Zakon č. 35/1967 Sb., o opatřenich proti znečišt'ovani ovzduši. 
niezgodne z zasadą „zanieczyszczający płaci”, ale zdaje sobie sprawę z trudności i kosztów związanych z wyliczaniem i pobieraniem opłat za takie zanieczyszczenia, wobec czego proponuje, aby dążąc do respektowania zasady „zanieczyszczający płaci” opodatkować paliwa w wysokości odpowiadającej zakładanym emisjom.

Przystępując do analizy opłat przewidzianych w czeskiej ustawie wodnej z 2001 r. zwraca uwagę, że ustawa ta w § 1 ust. 2 wskazuje wprost na obowiązek kierowania się zasadą „zanieczyszczający płaci”. Za znaczącą z punktu widzenia tej zasady uznaje przewidzianą w § 96 i 97 tej ustawy możliwość odroczenia opłat do $80 \%$ należnych, jeżeli odprowadzający ścieki realizuje na podstawie odpowiedniego pozwolenia oczyszczalnię lub inne urządzenie pozwalające zmniejszyć emisję. O odroczeniu decyduje Czeska Inspekcja Środowiska. Jeżeli inwestycje zostały zakończone w terminie i doprowadziły do usunięcia przekroczeń wskaźników zanieczyszczeń, Inspekcja nie egzekwuje opłat w wysokości, w której zostały odroczone.

Kolejną grupą opłat emisyjnych są opłaty za umieszczanie odpadów na składowisku wprowadzone w 1992 r. specjalną ustawą ${ }^{23}$, obecnie regulowane ustawą z 2001 r. o odpadach. Opłaty te mają charakter publicznoprawny (ponosi je także podmiot umieszczający odpady na własnym składowisku) i nie należy ich mieszać z opłatą należną prowadzącemu składowisko za świadczone przez niego usługi. Publicznoprawna opłata za składowanie obejmuje wszystkie odpady, ale za odpady niebezpieczne ponosi się opłatę dodatkową (tzv. rizikova složka). Stawki opłat zarówno podstawowe, jak i dodatkowe były pomyślane jako progresywnie rosnące $\mathrm{w}$ czasie, ta progresja się wszakże w 2009 r. skończyła. Autor informuje, że w ramach reformy opłat zapowiedzianej przez rząd w 2014 r. mają być wprowadzone opłaty za wszelkie sposoby usuwania odpadów uznanych za ekologicznie niekorzystne. Zwraca przy tym uwagę, że przewidziane w przepisach zwolnienie z opłat za składowanie tzw. materiału technologicznego (tj. odpadów umieszczanych na składowisku w celu zabezpieczenia składowiska)

23 Zakon č. 62/1992 Sb., o poplatcich za uloženi odpadi̊. 
jest nadużywane i pozwala uniknąć opłat przez „przekwalifikowanie" odpadów na materiał technologiczny. Nie jest to zgodne z zasadą „zanieczyszczający płaci” i dlatego autor proponuje objęcie obowiązkiem opłatowym także takiego materiału.

Na opłatach emisyjnych nie kończy się system opłat w prawie czeskim. Ondřej Vicha zwraca w szczególności uwagę na opłaty w komunikacji drogowej, występujące w dwóch postaciach: mytne (od pojazdów cięższych niż 3,5 tony) i časovy poplatek (od pojazdów do 3,5 tony). Środki pozyskane tytułem tych opłat zasilają Państwowy Fundusz Infrastruktury Komunikacyjnej. Autor informuje, że drogowy przewóz towarów wzrósł od końca lat 90. o połowę, przewóz międzynarodowy o $120 \%$. Wzmożony ruch ciężarowy pociąga za sobą uszkodzenia jezdni i dalsze nakłady zewnętrzne, które są przenoszone na społeczeństwo, rośnie ryzyko wypadków, hałas, zanieczyszczenia powietrza. Zdaniem autora regulacja prawna mytneho (tak oto średniowieczne „myto” posłużyło za nazwę instrumentu prawnego z XXI wieku) nie umożliwia objęcia nim niektórych kosztów zewnętrznych, jakimi są zanieczyszczenia, hałas czy korki drogowe, obejmuje tylko koszty związane z infrastrukturą drogową. Tak więc, w jego ocenie, regulacja mytneho niedostatecznie wdraża zasadę „zanieczyszczający płaci” i powinna być zmieniona przez włączenie rekompensaty za wskazane środowiskowe koszty zewnętrzne, co przyczyni się do ich ograniczenia.

Interesujące są rozważania autora nad najnowszym instrumentem ekonomicznym, jakim jest system handlu pozwoleniami na emisję gazów cieplarnianych, wywodzący się z Protokołu z Kioto, Ramowej konwencji ONZ w sprawie zmiany klimatu oraz prawa unijnego, który Republika Czeska wdrożyła najpierw ustawą z $2004 \mathrm{r}^{24}$, zastąpioną po ośmiu latach nową ustawą $^{25}$. Ta ostatnia jeszcze przewiduje przydzielanie bezpłatnych pozwoleń, co autor ocenia jako niezgodne z zasadą „zanie-

24 Zakon č. 695/2004 Sb., o podminkach obchodovani s povolenkami na emise sklenikovych plynů.

25 Zakon č. 383/2012 Sb., o podminkach obchodovani s povolenkami na emise sklenikovych plynů. 
czyszczający płaci", opowiadając się za poddaniem wszystkich pozwoleń systemowi nabywania ich na licytacji.

W podsumowaniu rozważań o prawie czeskim autor wraca jeszcze do najważniejszych opłat emisyjnych zauważając, że przestały one pełnić wyjściowo zakładaną funkcję motywacyjną (pełnią ją wyłącznie limity emisyjne) i obecnie funkcje opłat zostały ograniczone do fiskalnych.

Korespondując z rozważaniami czeskiego autora Ondřeja Vichy, warto wspomnieć, iż polskie podręczniki prawa środowiska - w odróżnieniu od czeskich - wśród katalogu podstawowych zasad wskazują zasadę „zanieczyszczający płaci”, obok niej wymieniając przykładowo: zasadę zrównoważonego rozwoju, zasadę kompleksowości, zasadę prewencji, zasadę przezorności, zasadę powszechnego dostępu do informacji o stanie środowiska i jego ochronie, zasadę uspołeczniania procesów podejmowania niektórych rozstrzygnięć oraz zasadę legalizmu ${ }^{26}$.

W systemie prawa polskiego zasada „zanieczyszczający płaci" stała się konsekwencją przepisu wyrażonego w art. 86 Konstytucji RP27. Zgodnie z jego treścią „Każdy jest obowiązany do dbałości o stan środowiska i ponosi odpowiedzialność za spowodowane przez siebie jego pogorszenie. Zasady tej odpowiedzialności określa ustawa". W odróżnieniu od prawa czeskiego polska ustawa Prawo ochrony środowiska ${ }^{28}$ formułuje expressis verbis $\mathrm{w}$ art. 7 oraz 7a treść zasady „zanieczyszczający płaci” stanowiąc, że „Kto powoduje zanieczyszczenie środowiska, ponosi koszty usunięcia skutków tego zanieczyszczenia", jak również „Kto może spowodować zanieczyszczenie środowiska, ponosi koszty zapobiegania temu zanieczyszczeniu" (art. 7). Ponadto w art. 7a wskazano, iż „Do bezpośredniego zagrożenia szkodą w środowisku i do szkody w środowisku w rozumieniu ustawy z dnia 13 kwietnia 2007 r. o zapobieganiu szkodom w środowi-

26 A. Lipiński, Prawne podstawy ochrony środowiska, Warszawa 2010, s. $31-34$.

27 Konstytucja Rzeczypospolitej Polskiej z dnia 2 kwietnia 1997 r., Dz.U. z 1997 r. Nr 78, poz. 483 ze zm.

28 Ustawa z dnia 27 kwietnia 2001 r. Prawo ochrony środowiska, t.j. Dz.U. z 2013 r. poz. 1232 ze zm. (dalej cyt.: p.o.ś). 
sku i ich naprawie stosuje się przepisy tej ustawy". Wyrażona w przytoczonych przepisach zasada odnosi się bezpośrednio do pojęcia „zanieczyszczenia”, które zostało zdefiniowane w art. 3 pkt 49 p.o.ś. Pod pojęciem tym rozumie się emisję, która może być szkodliwa dla zdrowia ludzi lub stanu środowiska, może powodować szkodę $\mathrm{w}$ dobrach materialnych, może pogarszać walory estetyczne środowiska lub może kolidować z innymi, uzasadnionymi sposobami korzystania ze środowiska.

W Polsce - podobnie jak w Czechach, na co wskazuje autor recenzowanej monografii - omawiana zasada wchodzi w relacje z innymi zasadami prawa środowiska. Niektórzy autorzy uważają, iż zasada ta jest konsekwencją zasad prewencji i przezorności, wyrażonych w art. 6 p.o.ś., ponieważ ma na celu uregulowanie kwestii kosztów tych działań ${ }^{29}$. Inni uważają, że jest powiązana jedynie z zasadą prewencji. Zdaniem P. Korzeniowskiego prewencyjna ochrona środowiska polega nie tylko na najwcześniejszym wykryciu możliwości wystąpienia zagrożenia dla środowiska, ale również chodzi w niej o znalezienie i usunięcie przyczyn, które sprzyjały powstaniu szkody ${ }^{30}$. Z kolei M. Górski uważa, iż zasada prewencji powinna zobowiązywać podmioty oddziałujące na środowisko do: „uwzględniania wymogów ochrony jeszcze przed podjęciem działalności; stosowania metod i technologii dla środowiska najkorzystniejszych (przede wszystkim tzw. czystych technologii, wykluczających powstanie lub poważnie zmniejszających zakres uciążliwości dla środowiska); przestrzegania zasad szczególnej ostrożności przy podejmowaniu działań o nieznanym wpływie na środowisko"31. Ponadto J. Sommer mówiąc o zasadzie prewencji jako obowiązku zapobiegania szkodzie twierdził, że „nie chodzi tylko o podejmowanie działań zapobiegających zdarzeniom, które szkodę muszą wywołać, lecz także o podjęcie stosownych działań (albo wstrzymanie się od działań), gdy powstanie szkody jest wysoce

29 Zob. B. Rakoczy [w:] Z. Bukowski, E. K. Czech, K. Karpus, B. Rakoczy, Prawo ochrony środowiska. Komentarz, Warszawa 2013, s. 58.

30 P. Korzeniowski, Zasady..., s. 363.

31 M. Górski, Ochrona środowiska jako zadanie administracji publicznej, Łódź 1992, s. 124. 
prawdopodobne w świetle doświadczenia"32. Przyjmuje się, że uzupełnieniem zasady prewencji jest zasada przezorności. Zdaniem A. Lipińskiego zasada przezorności ma miejsce „W razie podjęcia działalności, której negatywne skutki dla środowiska nie są $\mathrm{w}$ pełni rozpoznane, należy (dokładając należytej staranności) zawczasu przewidzieć możliwe konsekwencje takiej działalności, podejmując wszelkie dostępne środki zapobiegawcze"33. Zgodzić należy się z O. Vichą w kwestii, iż zasada prewencji zmienia podejście do zasady „zanieczyszczający płaci”, ponieważ wychodzi z założenia zapobiegania szkodom, aniżeli naprawienia już wyrządzonych.

Ze względu na wieloaspektowy charakter zasady „zanieczyszczający płaci" jest ona trudna do zdefiniowania. Bierze się ją pod uwagę zarówno przez pryzmat uwarunkowań ekonomicznych, prawnych jak i społecznych ${ }^{34}$. W nauce ekonomii uważa się, że mechanizm rynkowy nie uwzględnia wszystkich kosztów produkcji i konsumpcji ${ }^{35}$. Ja twierdzą J. Pakulska i M. Rutkowska, „zasada odpowiedzialności sprawcy wskazuje, że koszty unikania i usuwania szkód ekologicznych powinien ponosić ten, kto je spowodował. Ma to skłonić potencjalnych sprawców zagrożeń środowiska do rezygnacji lub też zmniejszenia szkodliwych wpływów przez ograniczenie stosowania szkodliwych dla środowiska towarów i technologii. Zasada ta wynika z przekonania i doświadczenia, że wpływanie na zanieczyszczających za pomocą bodźców finansowych daje lepsze rezultaty niż oddziaływanie na nich za pomocą instrumentów administracyjnych, takich jak nakazy i zakazy"36.

32 J. Sommer, Zasady ogóle i pojęcia niedookreślone w prawie ochrony przyrody, [w:] W. Radecki (red.), Teoretyczne podstawy prawa ochrony przyrody, Wrocław 2006, s. 95.

33 A. Lipiński, Prawne podstawy..., s. 33.

34 Zob. D. Danecka, Działalność górnicza w świetle wybranych rozwiązań prawa ochrony środowiska, [w:] Prawna regulacja geologii i górnictwa $w$ Polsce, Czechach i na Stowacji. Wybrane zagadnienia, pod red. G. Dobrowolskiego i G. Radeckiego, Katowice 2014, s. 69 i n.

35 Szerzej: M. Blaug, Teoria ekonomii. Ujęcie retrospektywne, Warszawa 1994, s. 390 i n.

${ }^{36}$ J. Pakulska, M. Rutkowska, Cele i zasady polityki ekologicznej w Polsce i Unii Europejskiej, [w:] M. Burchard-Dziubńska (red.), Integracja Polski z Unia 
W jaki sposób ta zasada jest realizowana w prawie polskim? Zdaniem P. Korzeniowskiego instrumentami działania w realizacji zasady „zanieczyszczający płaci” stosowanymi przez administrację publiczną są normy i opłaty. Wskazuje na trzy grupy norm. Po pierwsze: są to normy jakości środowiska, które w sposób wiążący wyznaczają poziom zanieczyszczeń lub uciążliwości, których nie należy przekraczać w danym środowisku lub jego części. Po drugie należą do nich normy dotyczące produktów, określające dopuszczalne poziomy zanieczyszczeń lub uciążliwości spowodowanych przez produkt. Po trzecie wskazuje na tzw. normy technologiczne, które z kolei obejmują: normy emisji, normy projektowe instalacji oraz normy eksploatacji, wskazujące warunki wymagane podczas eksploatacji stałych instalacji ${ }^{37}$. Ponadto istnieje możliwość nałożenia na sprawcę zanieczyszczenia obowiązku przestrzegania określonych wymagań ochronnych, które jednocześnie mogą zostać wykorzystane jako podstawa przy ustalaniu opłat i podatków. Wymagania te określane są za pomocą systemu standardów, przykładowo w ustawie Prawo ochrony środowiska zostały zdefiniowane w art. 3 pkt 33 oraz 34 standardy emisyjne oraz standardy jakości środowiska ${ }^{38}$. Autor ten podkreśla, że opłaty, jako instrument ekonomiczny, powinny być stosowane zgodnie z właściwą procedurą administracyjną, odpowiednio w stosunku do wielkości emitowanego zanieczyszczenia. Głównymi kosztami ponoszonymi przez zanieczyszczającego, są koszty prewencyjne zapobiegania zanieczyszczeniom. Jest on zobowiązany do ponoszenia tzw. kosztów niezbędnych, polegających na wyrównaniu szkód, a także kosztów dodatkowych, wynikających z administracyjno-prawnych obowiązków podmiotu ${ }^{39}$.

Mając na uwadze powyższe można powiedzieć, że w polskim prawie ochrony środowiska zasada ta wdrażana jest za

Europejska $w$ dziedzinie ochrony środowiska - problemy, korzyści, zagrożenia, t. 1, Łódź 2000, s. 104.

37 P. Korzeniowski [w:] Prawo ochrony środowiska, pod red. M. Górskiego, Warszawa 2014, s. 61.

38 Tamże, s. 62.

39 Zob. P. Korzeniowski, Zasady..., s. 432. 
pomocą środków finansowo prawnych, które stanowią w szczególności: 1) opłata za korzystanie ze środowiska; 2) administracyjna kara pieniężna; 3) zróżnicowane stawki podatków i innych danin publicznych służące celom ochrony środowiska (art. 272 p.o.ś.). Ponadto podmiot korzystający ze środowiska bez uzyskania wymaganego pozwolenia lub innej decyzji ponosi opłatę podwyższoną za korzystanie ze środowiska (art. 276 ust. 1 p.o.ś.). Zdaniem B. Draniewicza opłaty stanowią praktyczną realizację zasady „zanieczyszczający płaci” ${ }^{40}$. Polski ustawodawca ustanowił w art. 273 ust. 1 p.o.ś., że opłata za korzystanie ze środowiska jest ponoszona za: wprowadzanie gazów lub pyłów do powietrza; wprowadzanie ścieków do wód lub do ziemi; pobór wód oraz składowanie odpadów. Przyjmuje się, że opłaty powinny pełnić głównie funkcję: bodźcową (mającą zachęcać do działań ochronnych) oraz redystrybucyjną (jako źródło dochodów funduszy ochronnych) ${ }^{41}$. W doktrynie jednak zauważono, iż coraz częściej chodzi o funkcję fiskalną aniżeli bodźcową ${ }^{42}$. W tym miejscu można odnieść się do funkcji zasady „zanieczyszczający płaci” zaproponowanych przez O. Vichę. Uważamy, że wskazane przez czeskiego autora cztery funkcje: integracji ekonomicznej, redystrybucyjna, prewencyjna oraz kompensacyjna, można także odnieść do polskich regulacji. W rzeczywistości jednak największą przewagę zyskała funkcja redystrybucyjna. W związku z tym można dojść do wniosku, że zasada „zanieczyszczający płaci” $\mathrm{w}$ istocie daje przyzwolenie na zanieczyszczanie środowiska za opłatą. Nie chodzi więc o ochronę środowiska, ale o jej ekwiwalent w postaci opłaty za zanieczyszczenie.

Przechodząc do administracyjnych kar pieniężnych są one ponoszone za przekroczenie lub naruszenie warunków korzystania ze środowiska, ustalonych decyzją w zakresie wprowadza-

40 B. Draniewicz, Problem konstytucyjności opłat za korzystanie ze środowiska, „Państwo i Prawo” 2007, Nr 7, s. 78.

${ }^{41}$ W. Radecki, [w:] M. Górski, M. Pchałek, W. Radecki, J. Jerzmański, M. Bar, S. Urban, J. Jendrośka, Prawo ochrony środowiska. Komentarz, Warszawa 2014 , s. 759.

42 Zob. J. Sommer, Glosa do wyroku NSA z 2.12.1991 r., IV SA 1087/91, „Przegląd Sądowy” 1993, nr 7-8, s. 120. 
nia do środowiska emisji wskazanych w art. 272 ust. 1 p.o.ś., a także w zakresie magazynowania odpadów i emitowania hałasu do środowiska (art. 273 ust. 2 p.o.ś.). Uważamy, iż owe kary są trzecią (obok odpowiedzialności za przestępstwa oraz wykroczenia) formą odpowiedzialności karnej ${ }^{43}$, bądź jak sugeruje D. Szumiło-Kulczycka - formą odpowiedzialności administracyjno-karnej, jako jedną z form odpowiedzialności administracyjnej ${ }^{44}$. Bowiem sprawca naruszenia wymagań ochrony środowiska ma przecież obowiązek zapłacenia określonej sumy pieniężnej. Ustawodawca polski w art. 273 ust. 3 odsyła do przepisów ustawy o ochronie przyrody i przepisów ustawy - Prawo geologiczne i górnicze oraz innych ustaw, które określają zarówno odrębne przypadki jak i zasady ponoszenia opłat za korzystanie ze środowiska oraz administracyjnych kar pieniężnych.

Zasada „zanieczyszczający płaci” nie została więc uregulowana wyłącznie w ustawie Prawo ochrony środowiska. Odrębne regulacje możemy znaleźć nie tylko we wskazanych przez prawodawcę ustawach: o ochronie przyrody ${ }^{45}$ oraz prawo geologiczne i górnicze ${ }^{46}$, ale również między innymi w ustawach: prawo wodne ${ }^{47}$, o odpadach ${ }^{48}$, o ochronie gruntów rolnych i leśnych ${ }^{49}$. Polski prawodawca konkretyzuje ją więc również w innych aktach prawych, wskazując na negatywne dla środowiska skutki określonych działań, często używając pojęcia „zanieczyszczenia", jednakże inaczej je definiując. Posługując się przykładem Marcina Pchałka, można wskazać art. 22a u.g.r.l.,

43 Zob. W. Radecki, Odpowiedzialność prawna w ochronie środowiska, Warszawa 2002, s. 79.

44 Zob. D. Szumiło-Kulczycka, Prawo administracyjno-karne, Kraków 2004, s. 29.

45 Ustawa z dnia 16 kwietnia 2004 r. o ochronie przyrody, t.j. Dz.U. z 2013 r., poz. 627 ze zm. (dalej cyt.: u.o.p.).

46 Ustawa z dnia 9 czerwca 2011 r., Prawo geologiczne i górnicze, t.j. Dz.U. z 2015 r., poz. 196 (dalej cyt.: p.g.g.).

47 Ustawa z dnia 18 lipca 2001 r., Prawo wodne, t.j. Dz.U. z 2015 r., poz. 496 (dalej cyt.: u.p.w.).

48 Ustawa z dnia 14 grudnia 2012 r., o odpadach, Dz.U. z 2013 r., poz. 21 ze zm. (dalej cyt.: u.o.o).

49 Ustawa z dnia 3 lutego 1995 r. o ochronie gruntów rolnych i leśnych, t.j. Dz.U. z 2013 r., poz. 1205 ze zm. (dalej cyt.: u.g.r.l.). 
który pojęcie „zanieczyszczenia” ujmuje szerzej, wyróżniając spośród innych zanieczyszczeń powierzchni ziemi „zanieczyszczenie gruntów substancjami, preparatami, organizmami lub mikroorganizmami" 50 .

Podobnie jak w prawie czeskim, również w polskim systemie prawa zasada ta wprowadzona została zarówno przepisami o odpowiedzialności zawartymi w regulacjach ustawy prawo geologiczne i górnicze, (zgodnie z art. 146 p.g.g. odpowiedzialność za szkodę ponosi przedsiębiorca prowadzący ruch zakładu górniczego, wskutek którego wystąpiła szkoda), jak również za pomocą instrumentów ekonomicznych, takich jak przykładowo: opłaty wskazane w dziale VII p.g.g., opłaty za działalność określoną w koncesji na poszukiwanie lub rozpoznawanie złóż kopalin (art. 133 p.g.g.), opłaty eksploatacyjne (art. 134 p.g.g.), opłaty dodatkowe (art. 139 p.g.g.) oraz podwyższone (art. 140 p.g.g.). Ponadto ustawa prawo atomowe ${ }^{51}$ przewiduje odpowiedzialność cywilną za szkody jądrowe, uregulowaną w rozdziale 12, która zakłada między innymi w art. 100a naprawienie szkody jądrowej w środowisku naturalnym jako dobru wspólnym, które polegać ma na zwrocie kosztów środków przywracających stan środowiska naturalnego sprzed jego naruszenia zastosowanych przez upoważnione do tego organy lub na podstawie ich decyzji przez inne podmioty (ust. 2), jak również zwrot kosztów środków zapobiegawczych (ust. 3). Także ustawy odnoszące się poszczególnych komponentów środowiska wdrażają zasadę „zanieczyszczający płaci” podobnie jak w prawie czeskim, za pomocą instrumentów ekonomicznych w postaci opłat za zanieczyszczenie środowiska oraz regulacji prawnej środków naprawczych zmierzających do usunięcia niepożądanego stanu.

Przykładowo ustawa prawo wodne, która wprowadza własną definicję „zanieczyszczenia” oraz „zanieczyszczenia

50 M. Pchałek [w:] M. Górski, M. Pchałek, W. Radecki, J. Jerzmański, M. Bar, S. Urban, J. Jendrośka, Prawo ochrony..., s. 120.

51 Ustawa z dnia 29 listopada 2000 r. Prawo atomowe, t.j. Dz.U. z 2014 r., poz. 1512. 
wód morskich"52, w dziale VIII przewiduje odpowiedzialność za szkody. Zgodnie z art. 185 u.p.w. do naprawienia szkód, o których mowa w ustawie, z wyłączeniem przepisów art. 881-88q oraz art. 88t, stosuje się przepisy art. 186-188 tej ustawy (ust. 1). Z kolei do zapobiegania szkodom w wodach i naprawy szkód w wodach w rozumieniu ustawy z dnia 13 kwietnia 2007 r. o zapobieganiu szkodom $\mathrm{w}$ środowisku i ich naprawie stosuje się przepisy tej ustawy (ust. 2). Według art. 186 u.p.w. naprawienie szkody obejmuje pokrycie strat poniesionych przez poszkodowanego. Wysokość odszkodowania w drodze niezaskarżalnej decyzji ustala na żądanie poszkodowanego organ właściwy do wydania pozwolenia wodnoprawnego, a jeżeli szkoda nie jest następstwem pozwolenia wodnoprawnego - właściwy marszałek województwa.

Ciekawe rozwiązania $\mathrm{w}$ tym zakresie przewiduje także ustawa o odpadach. W art. 131 ust. 1 u.o.o. zakłada, że zarządzający składowiskiem odpadów jest obowiązany do ustanowienia zabezpieczenia roszczeń. Natomiast w przypadku wystąpienia negatywnych skutków w środowisku lub szkód w środowisku w rozumieniu ustawy z dnia 13 kwietnia 2007 r.

52 „Zanieczyszczeniem” zgodnie z art. 9 pkt 25a u.p.w. nazywa emisję w rozumieniu art. 3 pkt 4 ustawy z dnia 27 kwietnia 2001 r. - Prawo ochrony środowiska, która może być szkodliwa dla zdrowia ludzi lub stanu środowiska, w tym jakości ekosystemów wodnych lub ekosystemów lądowych bezpośrednio zależnych od ekosystemów wodnych, powodować szkodę w dobrach materialnych, pogarszać walory estetyczne środowiska lub kolidować z uzasadnionymi sposobami korzystania ze środowiska, w szczególności powodować zanieczyszczenie wód. Z kolei przez „zanieczyszczenie wód morskich” rozumie będące wynikiem działalności człowieka bezpośrednie lub pośrednie wprowadzanie do środowiska wód morskich, w tym dna i skały macierzystej znajdujących się na obszarze morza terytorialnego, wyłącznej strefy ekonomicznej Rzeczypospolitej Polskiej i wód przybrzeżnych, substancji lub energii, w tym podmorskiego hałasu, które wywołuje lub może wywoływać negatywne skutki, takie jak: a) straty w żywych zasobach i ekosystemach morskich, w tym utratę różnorodności biologicznej, b) zagrożenie dla zdrowia ludzkiego, c) utrudnienia w działalności morskiej, w tym w zakresie rybołówstwa, żeglugi, turystyki i rekreacji, oraz w innych sposobach korzystania z wód morskich, d) pogorszenie jakości wód morskich i zmniejszenie ich walorów estetycznych lub ograniczenie możliwości zrównoważonego korzystania z zasobów i usług morskich. 
o zapobieganiu szkodom w środowisku i ich naprawie, właściwy organ orzeka, w drodze decyzji, o przeznaczeniu środków z zabezpieczenia roszczeń na usunięcie tych skutków, o ile działań tych nie wykonał na własny koszt zarządzający składowiskiem odpadów art. 131 ust. 4 u.o.o. Wynika z tego, że „zanieczyszczający" może usunąć szkodę na własny koszt, bądź też ze środków z zabezpieczenia roszczeń.

Przechodząc do problematyki odpowiedzialności za zanieczyszczenie środowiska, czy za naruszenie wymagań ochrony środowiska, można powiedzieć, że - podobnie jak w prawie czeskim - w polskim prawie środowiska stanowi ona złożony problem, bowiem mamy do czynienia z przenikaniem się różnych rodzajów odpowiedzialności. W kwestii odpowiedzialności o charakterze represyjnym, możemy wyróżnić odpowiedzialność administracyjną (o której pisaliśmy wyżej w odniesieniu do administracyjnych kar pieniężnych) oraz odpowiedzialność karną za zanieczyszczenie środowiska, którą przewiduje polski kodeks karny ${ }^{53}$. Rozdział XXII zatytułowany „Przestępstwa przeciwko środowisku” również odwołuje się do pojęcia „zanieczyszczenia" w art. 182 k.k. oraz 186 k.k. ${ }^{54}$. Jednak największe problemy powstają w przypadku odpowiedzialności polegającej na przywróceniu należytego stanu uszkodzonych bądź zniszczonych elementów środowiska. Odpowiedzialność cywilna nie zawsze jest wystarczająca. Po pierwsze dlatego, że uruchomienie określonych nią środków zależne jest od woli poszkodowanego,

53 Ustawa z dnia 6 czerwca 1997 r. Kodeks karny, Dz.U. z 1997 r., Nr 88, poz. 553 ze zm. (dalej cyt.: k.k.).

54 Zgodnie z treścią art. $182 \S 1$ k.k.: „Kto zanieczyszcza wodę, powietrze lub powierzchnię ziemi substancją albo promieniowaniem jonizującym w takiej ilości lub w takiej postaci, że może to zagrozić życiu lub zdrowiu człowieka lub spowodować istotne obniżenie jakości wody, powietrza lub powierzchni ziemi lub zniszczenie w świecie roślinnym lub zwierzęcym w znacznych rozmiarach, podlega karze pozbawienia wolności od 3 miesięcy do lat 5". Z kolei art. 186 k.k. stanowi w $\S 1$, iż „Kto wbrew obowiązkowi nie utrzymuje w należytym stanie lub nie używa urządzeń zabezpieczających wodę, powietrze lub powierzchnię ziemi przed zanieczyszczeniem lub urządzeń zabezpieczających przed skażeniem promieniotwórczym lub promieniowaniem jonizującym, podlega grzywnie, karze ograniczenia wolności albo pozbawienia wolności do lat 2". 
a po drugie: często odmienne jest znaczenie pojęcia „szkody” występujące w prawie środowiska od tego przyjętego w kodeksie cywilnym ${ }^{55}$. Przewidzianą $\mathrm{w}$ kodeksie cywilnym odpowiedzialność odszkodowawczą można podzielić na: a) opartą na zasadzie winy (powstałą w wyniku zawinionego działania dłużnika); b) opartą na zasadzie ryzyka (szkoda powstaje w wyniku ruchu przedsiębiorstwa lub zakładu prowadzonego przez dłużnika); c) za tzw. produkt niebezpieczny (wytworzenie tzw. produktu niebezpiecznego jest przyczyną powstania szkody). O sposobie naprawienia szkody co do zasady decyduje poszkodowany, który może albo żądać przywrócenia stanu poprzedniego, albo zapłaty odpowiedniej sumy pieniężnej. Jednakże gdyby przywrócenie stanu poprzedniego było niemożliwe albo gdyby pociągało za sobą dla zobowiązanego nadmierne trudności lub koszty, roszczenie poszkodowanego ogranicza się do świadczenia w pieniądzu (art. $363 \S 1$ k.c.). W rzeczywistości instrument, który w założeniu służyć miał kompensacji wyrządzonych uszczerbków w środowisku, nie ma takiego charakteru. Przykładowo wskazać można na przewidziany w art. 15 ust. 4 prawa łowieckiego ${ }^{56}$ ekwiwalent (pieniężny) za zwierzynę bezprawnie pozyskaną ${ }^{57}$.

\section{WYZNACZENIE GRANIC ZASADY "ZANIECZYSZCZAJĄCY PŁACI”}

Esencją teoretyczną monografii Ondřeja Vichy jest jej rozdział 7, w którym autor stara się wyznaczyć granice zasady „zanieczyszczający płaci” (vymezeni principu „znečiśt’ovatel plati”)

55 Ustawa z dnia 23 kwietnia 1964 r., Kodeks cywilny, t.j. Dz.U. z 2014 r., poz. 121 ze zm. Zob. B. Rakoczy, Szkoda $w$ środowisku a szkoda wyrządzona oddziaływaniem na środowisko, [w:] Wybrane problemy prawa ochrony środowiska, pod red. B. Rakoczy, M. Pchałek, Warszawa 2010, s. 330 i n.

56 Ustawa z dnia 13 października 1995 r. Prawo łowieckie, t.j. Dz.U. z 2013 r. poz. 1226.

57 Zob. W. Radecki, Prawo łowieckie. Komentarz, Warszawa 2014, s. 126-132 . 
i zastanawia się nad niedociągnięciami w jej stosowaniu (nedostatky při jeho aplikaci). Za punkt wyjścia przyjmuje założenie, że zasada „zanieczyszczający płaci” jest wyrazem dążenia do tzv. internalizaci externalit. W teorii ekonomii chodzi o przeniesienie zewnętrznych kosztów z powrotem na ich sprawcę, który ponosi wszelkie koszty związane ze swoją działalnością. Tak pomyślana internalizacja może być częściowa lub pełna. Częściowa internalizacja jest ograniczona do pewnych kategorii kosztów. Pełna internalizacja obejmuje wszystkie koszty. W praktyce pełna internalizacja jest osiągana rzadko, ponieważ w najlepszym przypadku zanieczyszczający ponosi koszty kompensacji szkód, które dotykają nie wszystkich poszkodowanych. Dlatego nie ponosi kosztów szkód dotykających ofiar, które nie zostały objęte odszkodowaniami, i płaci tylko za rekompensowanie szkód, które są wyraźnie niższe od kosztów społecznych.

Generalnie stwierdzić można, że z zasady „zanieczyszczający płaci" wypływa wobec każdego, kto zanieczyści środowisko bądź spowoduje szkody w środowisku, obowiązek poniesienia kosztów związanych z ich usunięciem. Interpretacja tej zasady jest jednak stosunkowo złożona i nie zawsze całkiem jednoznaczna. W celu zastosowania i interpretacji tej zasady niezbędne jest:

1) zdefiniowanie podstawowych pojęć (zanieczyszczenie, szkoda w środowisku, ujma ekologiczna),

2) zidentyfikowanie zanieczyszczającego,

3) kwantyfikacja sumy, którą zanieczyszczający miałby zapłacić,

4) określenie, na czyją rzecz płatność miałaby nastąpić.

Odnosząc się do pojęć podstawowych autor wskazuje, że możliwe są dwa odmienne podejścia. Pierwsze oparte na bezprawności wychodzi z założenia, że zanieczyszczenie powstaje tylko przy przekroczeniu tzw. standardu jakości (limitów emisyjnych). Według tej koncepcji nie jest tak, że jakakolwiek emisja powoduje zanieczyszczenie; aby uznać emisję za zanieczyszczenie, substancja wniesiona do środowiska musi przekroczyć limit emisyjny (standard jakości) stanowiony bądź bezpośrednio aktem prawnym, bądź przez organ działający na jego podstawie. 1/2015 Jeżeli te progi są respektowane, to do emitenta zasada „zanie- 
czyszczający płaci" nie ma zastosowania. Temu podejściu odpowiada definicja pojęcia uszkodzenia środowiska (poškozovani životneho prostředi) zamieszczona w $\S 8$ ust. 2 czeskiej ustawy o środowisku, która głosi, że jest nim pogorszenie stanu środowiska zanieczyszczeniem lub innym działaniem człowieka ponad miarę (nad miru) ustanowioną przez przepisy szczególne.

Drugie podejście wychodzi z założenia, że zanieczyszczenie nie jest zależne od przekroczenia określonego limitu emisyjnego. Zanieczyszczenie nie zależy od tego, czy doszło do niego bezprawnie czy zgodnie z prawem, istnieje jako funkcja wpływów emisyjnych, kiedy następstwo jest znacznie ważniejsze niż przyczyna. W tym ujęciu zanieczyszczenie jest związane ze szkodą i reżimem odpowiedzialności za nią. Autor powołując się na literaturę światową preferuje to drugie podejście, co wzmacnia odesłaniem do aktów prawa międzynarodowego i unijnego.

Problem identyfikacji zanieczyszczającego jest stosunkowo prosty w przypadkach zanieczyszczeń pochodzących z urządzeń przemysłowych, jest nim po prostu prowadzący ruch (provozovatel) takiego urządzenia. Znacznie bardziej złożona jest identyfikacja w przypadkach odnoszących się do komunikacji lub konsumpcji. Przyjmuje się, że zanieczyszczającym jest podmiot, który odgrywa zasadniczą rolę w zanieczyszczeniu. Tytułem przykładu: nie musi to być osoba, która obchodzi się z odpadem, może to być producent wyrobu, który następnie stanie się odpadem. Na tym spostrzeżeniu opiera się unijna koncepcja rozszerzonej odpowiedzialności producenta.

Zdaniem autora zasada „zanieczyszczający płaci” pierwotnie nie zajmowała się odpowiedzialnością prawną, ponieważ nie była ukierunkowana na osobę odpowiedzialną za zanieczyszczenia w znaczeniu prawnym. Dopiero wprowadzenie reżimu odpowiedzialności za szkody w środowisku, i to reżimu odpowiedzialności obiektywnej (bez względu na zawinienie) zrazu w prawie międzynarodowym, następnie w unijnym umożliwiło jednoznacznie identyfikować sprawcę zanieczyszczenia, który zgodnie z zasadą „zanieczyszczający płaci” ponosi związane z tym koszty.

Ondřej Vicha zauważa, że główne różnice między definicjami zasady „zanieczyszczający płaci” odnoszą się do zasięgu 
kosztów, które zanieczyszczający ma ponosić. Na tym tle wprowadza rozróżnienie:

- zasady „zanieczyszczający płaci” w znaczeniu węższym, kiedy owe koszty są ograniczone do prewencji i kontroli; tę postać zasady określa się także mianem podstawowej (zakladni princip „znečišstovatel plati”),

- zasady „zanieczyszczający płaci” w znaczeniu szerszym, kiedy zasada ta obejmuje wszelkie koszty; tę postać zasady określa się także mianem rozszerzonej (rozšiřeny princip „znečišt'ovatel plati”).

Na tle tego rozróżnienia autor przedstawia ewolucję zasady od pierwotnych nakładów na przedsięwzięcia, które z mocy ustawy powinien podjacć, aby zmniejszyć zanieczyszczenia u źródła lub zapobiec ich przenikaniu do środowiska, poprzez nakłady na realizację przedsięwzięć nakazanych przez organy administracji, a także na pomiary, badanie stanu środowiska (monitoring), obserwację, kontrolę i inspekcję, do nakładów na naprawienie szkód wyrządzonych zanieczyszczeniem. Autor zwraca uwagę na jeszcze jedną linię ewolucyjną: początkowo zasada obejmował tylko kontynuowane lub chroniczne zanieczyszczenia, które trzeba było zmniejszyć, stopniowo zaczęła obejmować także ponoszenie kosztów związanych z usuwaniem następstw zanieczyszczeń awaryjnych. Ostateczny wniosek autora jest taki, że zasada „zanieczyszczający płaci” z biegiem lat stała się identyczna z zasadą pełnej internalizacji kosztów zewnętrznych związanych z zanieczyszczeniami. Zanieczyszczający musi ponosić jeżeli nie wszystkie, to co najmniej większość kosztów związanych z zanieczyszczeniami. Ten szerszy wymiar internalizacji przejawia się zwłaszcza w ramach państw członkowskich OECD. Widać go także w innych organizacjach międzynarodowych (deklaracja z Rio de Janeiro 1992), ale w prawie wewnętrznym zakres internalizacji kosztów zewnętrznych różni się w zależności od tego, jaką politykę państwa te prowadzą.

W kwestii beneficjenta zasady „zanieczyszczający płaci” autor wyróżnia dwa podejścia:

- prywatnoprawne, oparte na ochronie praw właścicielskich, polegające na wyrównywaniu szkód na mieniu 
i osobie za pośrednictwem mechanizmów odpowiedzialności cywilnej,

- publicznoprawne, polegające na wprowadzeniu różnych płatności (opłaty, podatki, zakup praw do emisji, ale także kary pieniężne) wpływających do budżetów lub specjalnych funduszy.

W końcowej części monografii Ondřej Vicha wskazuje na niedociągnięcia w stosowaniu analizowanej zasady (nedostatky $v$ aplikaci principu „znečišt'ovatel plati”). Przychyla się po poglądu wyrażanego przez niektórych autorów zachodnich, że jest to przede wszystkim zasada ekonomiczna, a nie wiążąca reguła prawna. Są takie sytuacje, kiedy zidentyfikowanie zanieczyszczającego i zwłaszcza wykazanie związku przyczynowego między jego zachowaniem a szkodą jest bardzo trudne lub w ogóle niemożliwe (zanieczyszczenie wód podziemnych związkami azotu, zanieczyszczenie wód przybrzeżnych, ubytek lasu, erozja gleby, zmiany klimatyczne, smog, a przede wszystkim tzw. zanieczyszczenia historyczne). Zauważa, że zasada „zanieczyszczający płaci" jest efektywna tylko wtedy, gdy zanieczyszczającego można zidentyfikować i jest on wypłacalny, jeżeli nie trzeba sięgać do innych mechanizmów w postaci specjalnych funduszy lub przejęcia obowiązków przez państwo, co w krajach postsocjalistycznych wystąpiło $\mathrm{z}$ pełną mocą $\mathrm{w}$ związku z przemianami własnościowymi.

Za najpoważniejszą przeszkodę pełnej realizacji zasady „zanieczyszczający płaci” uważa autor możliwość odzwierciedlenia kosztów związanych $\mathrm{z}$ zanieczyszczeniami $\mathrm{w}$ cenach wyrobów lub usług. Wtedy zasada ta traci swój sens, a koszty w ostatecznym rachunku ponosi konsument. Dróg wyjścia poszukuje w większej aktywności społeczeństwa, realizacji prawa do informacji o środowisku, a także w koncepcji społecznej odpowiedzialności firm.

Podsumowując należy stwierdzić, iż niewątpliwie wyznaczenie granic zasady „zanieczyszczający płaci” jest niezwykle trudne, o ile jest w ogóle możliwe. Zgodzić należy się z sugestiami czeskiego autora, jakoby nie jest możliwe pełne zastosowanie i interpretacja tej zasady. Zauważyć należy, iż - również w polskim systemie - podstawowe pojęcia nie zostały jasno zde- 
finiowane, niejednokrotnie nie jest możliwe zidentyfikowanie zanieczyszczającego, jak również nie została skwantyfikowana suma, którą zanieczyszczający miałby zapłacić, czy też nie w każdym przypadku określono na czyją rzecz należy dokonać płatności.

Ponadto zwrócić należy uwagę na to, że w polskim systemie prawa możliwe są liczne odstępstwa od realizacji tej zasady. Zostały one wskazane w ustawie z dnia 13 kwietnia 2007 r. o zapobieganiu szkodom w środowisku i ich naprawie ${ }^{58}$. Po pierwsze do klauzul derogacyjnych zaliczyć należy ograniczenia czasowe wyrażone w art. 4 pkt 1 u.sz., zgodnie z którym, jej przepisów nie stosuje się 1) do bezpośredniego zagrożenia szkodą w środowisku lub szkody w środowisku, która zaistniała przed dniem 30 kwietnia 2007 r. lub wynika z działalności, która została zakończona przed dniem 30 kwietnia 2007 r., a także jeżeli od emisji lub zdarzenia, które spowodowały bezpośrednie zagrożenie szkodą lub szkodę w środowisku, upłynęło więcej niż 30 lat, w tym do historycznego zanieczyszczenia powierzchni ziemi. Po drugie przepisów o zapobieganiu szkodom w środowisku i ich naprawie nie stosuje się jeżeli bezpośrednie zagrożenie szkodą w środowisku lub szkoda w środowisku zostały spowodowane przez: a) konflikt zbrojny, działania wojenne, wojnę domową lub powstanie zbrojne, b) katastrofę naturalną $\mathrm{w}$ rozumieniu przepisów ustawy z dnia 18 kwietnia 2002 r. o stanie klęski żywiołowej59 , c) działalność, której głównym celem jest obronność i bezpieczeństwo państwa, bezpieczeństwo międzynarodowe lub której jedynym celem jest ochrona przed klęską żywiołową (art. 4 pkt 2 u.sz.). Z kolei art. 5 u.sz. wyłącza jej zastosowanie w odniesieniu do szkód jądrowych (w zakresie uregulowanym w ustawie z dnia 29 listopada 2000 r. Prawo atomowe).

W świetle powyższych rozważań uważamy, iż w obecnym stanie prawnym nie jest możliwe sztywne określenie granic zasady „zanieczyszczający płaci”. W obu porządkach prawnych możemy wskazać zarówno szereg podobieństw jak i różnic

58 T.j. Dz.U. z 2014 r., poz. 1789 (dalej cyt.: u.sz.).

59 T.j. Dz.U. z 2014 r., poz. 333 ze zm. 
w pojmowaniu tej zasady. W odróżnieniu od czeskiego systemu prawa, gdzie występuje pojęcie „ujmy ekologicznej”, polski ustawodawca posługuje się pojęciem „zanieczyszczenia”. Ponadto polska ustawa Prawo ochrony środowiska wprost wyraża zasadę „zanieczyszczający płaci”, podczas gdy czeska ustawa o środowisku nie wspomina o niej wprost - wyprowadza się ją z regulacji o odpowiedzialności za ujmę ekologiczną i instrumentów ekonomicznych. W przypadku „ujmy ekologicznej” nie jest możliwa finansowa rekompensata, istnieje możliwość wyliczenia kosztów przywrócenia stanu poprzedniego bądź kosztów przedsięwzięć kompensacyjnych - w czeskim porządku prawnym pierwszeństwo ma restytucja naturalna (przywrócenie stany pierwotnego). W Polsce natomiast pierwszeństwo przypada restytucji finansowej (zapłacie odpowiedniej sumy pieniężnej). Podobne są między innymi instrumenty realizacji tej zasady. Przykładowo wskazać można, iż w obu porządkach prawnych występuje system opłat za zanieczyszczenie środowiska czy kar pieniężnych.

Monografia poświęcona zasadzie „zanieczyszczający płaci” zasługuje na uznanie. Uwagi sformułowane przez autora są niezwykle cenne nie tylko z punktu widzenia doktryny prawa ochrony środowiska, ale również praktyki. Badania Ondřeja Vichy mogą posłużyć jako asumpt do badań komparatystycznych nad ową zasadą w polskiej doktrynie. Dotychczas nikt nie przeprowadził wyczerpujących badań w tym zakresie.

\section{BIBLIOGRAFIA}

Blaug M., Teoria ekonomii. Ujęcie retrospektywne, Warszawa 1994. Badowska-Domagała E., Barczak A., Bartniak K., Bomanowski B., Górski M. (red.), Jaworowicz-Rudolf A., Kaźmierska-Patrzyczna A., Kaźmierska-Stępniak K., Kempa A., Kierzkowska J. S., Korzeniowski P., Król M. A., Łysek M., Michałowska-Rębowska J., Michalak M., Prawo ochrony środowiska, Warszawa 2014.

Bukowski Z., Czech E.K., Karpus K., Rakoczy B., Prawo ochrony środowiska. Komentarz, Warszawa 2013. 
Danecka D., Działalność górnicza w świetle wybranych rozwiązań prawa ochrony środowiska, [w:] Prawna regulacja geologii i górnictwa $w$ Polsce, Czechach $i$ na Stowacji. Wybrane zagadnienia, pod red. G. Dobrowolskiego i G. Radeckiego, Katowice 2014.

Damohorsky M., Pravni odpovědnost za ztraty na životnim prostředi, Praha 1999.

Damohorsky M. a kolektiv, Pravo životniho prostředi, Praha 2010.

Draniewicz B., Problem konstytucyjności opłat za korzystanie ze środowiska, „Państwo i Prawo” 2007, nr 7.

Eliaš K. a kolektiv, Novy občansky zakonik $s$ aktualizovanou dìvodovou zpravou a rejstřikem, Ostrava 2012.

Górski M., Ochrona środowiska jako zadanie administracji publicznej, Łódź 1992.

Górski M., Pchałek M., Radecki W., Jerzmański J., Bar M., Urban S., Jendrośka J., Prawo ochrony środowiska. Komentarz, Warszawa 2014.

Jančařova I., Bahyl'ova L., Pekarek M., Průchova I., Vomačka V., Odpovědnost v pravu životniho prostředi - současny stav a perspektivy, Brno 2013.

Jelinek J. a kolektiv, Trestni pravo hmotne. Obecna čast. Zvlaštni čast, Praha 2013.

Kenig-Witkowska M. M., Międzynarodowe prawo środowiska. Wybrane zagadnienia systemowe, Warszawa 2011.

Korzeniowski P., Zasady prawne ochrony środowiska, Łódź 2010.

Lipiński A., Prawne podstawy ochrony środowiska, Warszawa 2010.

Pakulska J., Rutkowska M., Cele i zasady polityki ekologicznej w Polsce i Unii Europejskiej, [w:] Burchard-Dziubńska M. (red.), Integracja Polski z Uniq Europejska $w$ dziedzinie ochrony środowiska problemy, korzyści, zagrożenia, t. 1, Łódź 2000.

Radecki W., Odpowiedzialność prawna w ochronie środowiska, Warszawa 2002.

Radecki W., Prawo towieckie. Komentarz, Warszawa 2014.

Rakoczy B., Szkoda w środowisku a szkoda wyrządzona oddziaływaniem na środowisko, [w:] Wybrane problemy prawa ochrony środowiska, pod red. B. Rakoczy, M. Pchałek, Warszawa 2010.

Sommer J., Glosa do wyroku NSA z 2.12.1991 r., IV SA 1087/91, „Przegląd Sądowy" 1993, nr 7-8.

Sommer J., Zasady ogóle i pojęcia niedookreślone $w$ prawie ochrony przyrody, [w:] W. Radecki (red.), Teoretyczne podstawy prawa ochrony przyrody, Wrocław 2006. 
Stejskal V., Vicha O., Zakon o předchazeni ekologicke ujmě a o jeji napravěs komentařem, souvisejicimi predpisy a s uvodem do problematiky ekologicko-pravni odpovědnosti, Praha 2009.

Szumiło-Kulczycka D., Prawo administracyjno-karne, Kraków 2004.

Kontakt e-mail:

daria.danecka@gmail.com 